\title{
Program Kemitraan dalam Pengembangan Pangan Lokal Singkong Krispi Rumput Laut untuk Meningkatkan Pendapatan Masyarakat
}

\section{(The Partnership Program in Development of Local Food Cassava Seaweed Crispy to Increase Community Income)}

\author{
Tati Atia Ngangun, Ismael Marasabessy* \\ Jurusan Teknologi Hasil Perikanan, Politeknik Perikanan Negeri Tual, Jl. Langgur Sathean Km 6, \\ Maluku Tenggara 97116. \\ *Penulis Korespondensi: ismael_mabes@yahoo.com \\ Diterima Oktober 2018/Disetujui Juli 2019
}

\begin{abstract}
ABSTRAK
Mitra program kemitraan masyarakat (PKM) ini adalah kelompok pengolah singkong di Desa Ibra, Kabupaten Maluku Tenggara. Mitra dapat diklasifikasikan ke dalam masyarakat yang produktif secara ekonomi, tetapi mereka masih menghadapi banyak masalah dalam proses produksi dan pemasaran. Tujuan kegiatan ini adalah untuk meningkatkan pendapatan mitra kelompok pengolah keripik singkong, dan meningkatkan nilai tambah ubi singkong dengan penambahan rumput laut menjadi keripik singkong yang tinggi serat. Pelaksanaan kegiatan dilakukan dalam tiga tahap, pertama memproduksi tepung singkong dengan metode press ditingkatkan, kedua memproduksi piring singkong, dan ketiga memproduksi keripik singkong rumput laut krispi (SKRL). Hasil kegiatan menunjukkan bahwa produk SKRL cukup menarik bagi konsumen. Dengan perbaikan bentuk, rasa, dan kemasan SKRL telah menjadi salah satu oleh-oleh khas komunitas Kei. Strategi pemasaran yang diadopsi adalah peningkatan kemasan menggunakan dua jenis kemasan, yaitu kemasan primer dengan plastik propilen (PP) dan kemasan sekunder menggunakan kotak kertas. Singkong rumput laut yang dihasilkan sangat disukai oleh konsumen karena rasanya yang enak dan krispi. Penggunaan alat press ulir menghasilkan keripik singkong dengan kadar HCN yang sangat rendah sehingga sangat aman dikonsumsi. Penghasilan mitra meningkat, hasil penjualan selama 6 bulan kegiatan mencapai 600 kotak dengan nilai Rp 10.000 .000 .
\end{abstract}

Kata kunci: pendapatan, rumput laut, singkong krispi

\begin{abstract}
Partner of the community partnership program on this study is a group of cassava chips processing located in the village of Ibra, Southeast Maluku district. Partners can be classified into economically productive societies, but they still face many problems in the production and marketing process. The purpose of this activity was to increase the income of the cassava chip processing group partners, and to increase the added value of cassava root by adding seaweed into high fiber cassava chips. The activity was carried out in three stages, firstly producing cassava flour with an improved press method, secondly producing cassava plates, and thirdly producing cassava krispi seaweed chips(SKRL). The results of the activity showed that SKRL products were quite attractive to consumers. With the improvement of the form, taste and packaging of SKRL had become one of the typical souvenirs of the Kei community. The marketing strategy adopted was to increase packaging using two types of packaging, namely primary packaging with propilen plastic (PP) and secondary packaging using paper boxes. Seaweed cassava produced was very preferred by consumers because it tastes good and crispy. The use of a screw press produced cassava chips with very low HCN levels so it is very safe to consume. The partner's income increased, the sales during the 6 months of activities reached 600 boxes with a value of IDR 10,000,000.
\end{abstract}

Keyword: cassava krispi, income, seaweed

\section{PENDAHULUAN}

Desa Ibra terletak di Kecamatan Kei Kecil, Kabupaten Maluku Tenggara mempunyai luas sekitar $20.135 \mathrm{~m}^{2}$. Total jumlah penduduknya 562 jiwa terbagi atas laki-laki 262 jiwa dan perempuan 364 jiwa. Secara umum tingkat pendidikan masyarakat di desa ini sekitar 30\% 
merupakan tamatan sekolah dasar, termasuk mitra yang dibantu dalam kegiatan PKM ini seluruh anggota tamatan SD. Potensi desa ini berasal dari laut dan darat. Potensi laut didominasi rumput laut dan jenis ikan-ikan karang, sedangkan potensi darat didominasi singkong (tinggi $\mathrm{HCN}$ ) oleh masyarakat lokal disebut enbal. Sejalan dengan kondisi potensi daerah yang ada, maka sebagian besar masyarakat $(52 \%)$ bermata pencaharian sebagai nelayan tangkap dan nelayan budi daya ikan dan rumput laut, sedangkan sekitar $40 \%$ sebagai petani singkong (enbal), tanaman umur pendek lainnya (sayuran), pegawai negeri sipil, dan wiraswasta.

Sebagai makanan khas daerah, singkong atau enbal dikonsumsi oleh semua lapisan masyarakat. Makanan ini dihidangkan dengan berbagai macam cara, yaitu disangrai yang disebut enbal goreng, didadar disebut enbal bubuhuk, dan dibakar/dipanggang disebut enbal bubes (porna). Banyak kelemahan yang ditemui dalam proses produksinya dan secara umum permasalahan ini terbagi dua, yaitu masalah produksi dan pemasaran. Masalah produksi yang teridentifikasi adalah rendahnya sanitasi dan higienis dalam proses pemerasan singkong parut dan produksi krispi singkong, waktu pemerasan yang terlalu lama sekitar 6-8 jam, kemasan yang menggunakan plastik biasa tanpa label serta bentuk dan rasanya yang masih didominasi selera lokal, yaitu agak besar dan rasanya agak hambar. Sementara itu, masalah manajemen dan pemasaran adalah tidak adanya pencatatan keuangan sehingga tidak mengetahui pengeluaran dan keuntungan usaha secara pasti.

Usaha ini sudah berlangsung turun temurun yang dilakukan secara tradisional. Dalam perkembangannya, pangan lokal ini cukup diminati oleh penduduk lokal sebagai cemilan Usaha pengolahan dan penjualan enbal ini cukup menjanjikan untuk memberikan penghasilan yang lumayan kepada petani, asalkan dibuat sedemikian rupa sehingga lebih mempunyai daya saing. Hasil penelitian Tapotubun (2010) dan Marasabessy et al. (2014) menunjukkan kandungan gizi enbal lempeng sangat terbatas, masih perlu ditingkatkan lagi terutama untuk serat dan mineral (Tabel 1).

Produksi rumput laut Kepulauan Kei dalam 5 tahun terakhir (Gambar 1 ) cukup tinggi dan terus mengalami peningkatan (DKP Malra 2018). Kondisi ini menyebabkan penyediaan serat yang berasal dari rumput laut cukup besar. Hasil penelitian Marasabessy et al (2017) me- nunjukkan rumput laut Eucheuma cottonii mengandung serat cukup tinggi, yakni sekitar $66 \%$ (Tabel 1). Serat sangat penting dalam proses pencernaan makanan di tubuh. Kekurangan serat dapat menyebabkan konstipasi (sembelit), apenaistis (radang usus buntu), hemoroid (wasir), diabetes melitus, penyakit jantung koroner, dan batu ginjal (Almatsier 2009). Secara tradisional rumput laut telah lama digunakan sebagai bahan makanan dan obat-obatan karena kaya akan mineral, elemen makro, dan elemen mikro lainnya. Beberapa jenis rumput laut mengandung mineral penting yang berguna untuk metabolisme tubuh seperti iodium, kalsium, dan selenium (Burtin 2006). Agar pemanfaatan rumput laut dapat lebih maksimal sebagai sumber serat, serta ada peningkatan kualitas pangan lokal maka perlu dilakukan diversifikasi produk enbal, yakni dengan melakukan penambahan rumput laut ke dalam enbal serta membuatnya lebih diterima masyarakat luas sebagai cemilan oleh-oleh khas Kepulauan Kei.

Singkong krispi atau enbal krispi merupakan produk yang diolah dengan cara dua kali pemanggangan menyebabkan tepung singkong menjadi kompak dan renyah. Singkong krispi

Tabel 1 Komposisi gizi tepung singkong dan tepung rumput laut

\begin{tabular}{lrr}
\hline \multicolumn{1}{c}{ Parameter (\%) } & $\begin{array}{c}\text { Tepung } \\
\text { singkong }\end{array}$ & $\begin{array}{c}\text { Tepung } \\
\text { rumput laut }\end{array}$ \\
\hline Kadar air & 38,55 & 41,36 \\
Protein & 1,03 & 0,70 \\
Lemak & 0,43 & 0,20 \\
Kadar abu & 0,88 & 3,40 \\
Serat makanan & 4,02 & 66,4 \\
\hline Asam sianida (mg/kg) & $<3$ & Tidak \\
& & terdeteksi \\
\hline
\end{tabular}

Keterangan: batas maksimal kandungan HCN dalam tepung singkong (SNI 1992): maksimal $40 \mathrm{mg} / \mathrm{kg}$

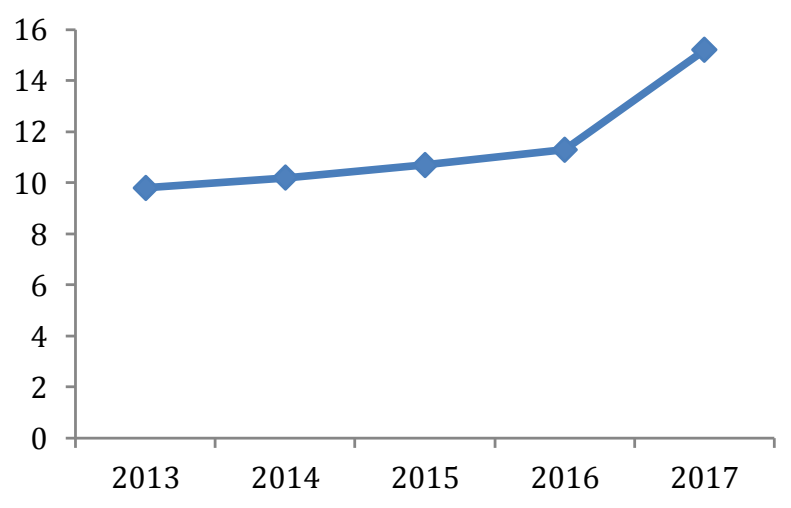

Gambar 1 Produksi rumput laut E. cottonii (ton) di Kabupaten Maluku Tenggara selama lima tahun terakhir pada tahun 2013-2017. 
merupakan produk baru (diversifikasi) dari singkong krispi yang diproduksi masyarakat. Hasil penelitian Marasabessy et al (2014) menunjukkan bahwa produk singkong krispi (enbal krispi) lebih disukai dan mempunyai komposisi serat dan mineral lebih baik. Sedangkan kandungan asam sianida (HCN) sangat rendah, jauh di bawah batas SNI yakni maksimal sebesar 40 $\mathrm{mg} / \mathrm{kg}$ (SNI 1992). Dengan demikian, kondisi produk ini sangat layak dipasarkan karena mendapat respons yang cukup baik dari masyarakat.

Tujuan kegiatan ini adalah agar kelompok mitra dapat 1) Memperbaiki proses penanganan dan pengolahan yang sesuai standar sanitasi dan higienis sehingga menambah tingkat kesukaaan konsumen; 2) Melakukan pengemasan yang memenuhi standart; dan 3) Mengetahui cara pemasaran, membuat pembukuan usaha, menghitung untung rugi (analisis keuangan). Tujuan khusus kegiatan ini adalah meningkatkan nilai tambah (added value) singkong dan rumput laut menjadi singkong krispi (enbal krispi) dengan kandungan serat dan mineral yang lebih tinggi.

\section{METODE PELAKSANAAN KEGIATAN}

\section{Waktu dan Tempat}

Kegiatan ini dilakukan selama 6 bulan dimulai Maret-Agustus 2018 bertempat di lokasi mitra Desa Ibra, Kecamatan Kei Kecil, Kabupaten Maluku Tenggara. Kegiatan penyuluhan dan pelatihan pengolahan singkong krispi rumput laut dilakukan di lokasi mitra dan di laboratorium Pengolahan Ikan Politeknik Perikanan Negeri Tual.

\section{Bahan dan Alat}

Bahan baku utama adalah singkong (Manihot sp.), rumput laut Eucheuma cottonii dan bahan tambahan meliputi telur satu butir, mentega sebanyak 300 gr, susu cair sebanyak 90 g, gula sebanyak $250 \mathrm{~g}$, dan vanili sebanyak $4 \mathrm{~g}$. Rumput laut Eucheuma cottonii digunakan sebagai bahan baku karena jenis ini yang dominan dibudidayakan oleh masyarakat serta mempunyai kandungan serat pangan tinggi. Produk dikemas dengan menggunakan kemasan primer dari plastik polipropilen dan kemasan sekunder dari kertas tebal (kardus) yang dilaminating. Peralatan utama yang digunakan meliputi alat pres ulir, alat penggilingan tepung, blender, mikser, oven hok, kompor hok, dan alat cetak singkong lempeng (porna).

\section{Metode Kegiatan}

Tiga metode pelaksanaan yang diterapkan untuk mengatasi permasalahan mitra adalah memberi penyuluhan, pelatihan, pendampingan, dan evaluasi. Kegiatan penyuluhan diberikan oleh tim pelaksana dengan menyampaikan materi terkait teknik pengolahan singkong krispi yang baik, teknik budi daya dan panen rumput laut yang baik, pemilihan strategi pemasaran dan cara menerapkannya, cara membuat buku kas, serta cara menghitung saldo kas bulanan. Kegiatan pelatihan dibuat berdasarkan materi penyuluhan meliputi pelatihan produksi singkong krispi rumput laut dan pelatihan manajemen keuangan meliputi cara membuat buku kas usaha.

Kegiatan pendampingan dilakukan dengan melakukan kontrol terhadap kegiatan produksi dan manajemen usaha mitra selama 6 bulan. Membantu mitra mengurus izin pangan industri rumah tangga (PIRT), mendisain kemasan, serta membuat SOP produksi agar proses produksi singkong krispi tetap berjalan sesuai materi penyuluhan yang telah diberikan. Selanjutnya membantu mitra dalam proses pemasaran produk serta memberi masukan terhadap permasalahan selama kegiatan produksi PKM, baik masalah seputar kegiatan produksi maupun manajemen dan pemasaran. Sementara itu, kegiatan evaluasi dilakukan terhadap proses dan produk singkong krispi yang dihasilkan, dengan cara memberi soal post test untuk mengetahui pengetahuan dan pemahaman mitra terhadap kegiatan produksi singkong krispi.

\section{Prosedur Kegiatan}

Kegiatan terdiri dari tiga tahap meliputi: 1) Produksi tepung singkong (enbal) yang akan digunakan sebagai bahan baku singkong krispi rumput laut; 2) Produksi singkong lempeng; dan 3) Pembuatan singkong krispi rumput laut. Sebelum dipasarkan, dilakukan juga uji organoleptik oleh tim PKM dan mitra. Selain itu, dilakukan juga pelatihan pembukuan kas usaha untuk mengetahui arus kas masuk dan keluar serta mengetahui saldo kas.

\section{HASIL DAN PEMBAHASAN}

\section{Produksi Singkong Krispi Rumput Laut}

Produksi singkong krispi rumput laut (SKRL) yang dilakukan oleh mitra mengalami banyak perubahan setelah dilakukan penyuluhan oleh tim program kemitraan masyarakat. Kekurangan 
dalam proses produksi singkong lempeng yang selama ini dilakukan oleh mitra seperti sanitasi higienis alat dan lingkungan yang rendah, yang mana air perasan singkong parut yang selalu dibiarkan tergenang di bawah tempat pengepresan, serta alat pres yang kotor karena terbuat dari kayu batangan dan batu karang, telah mengalami banyak perbaikan. Melalui kegiatan penyuluhan pentingnya sanitasi higieni dalam proses produksi singkong krispi, mitra melakukan beberapa perbaikan di antaranya mengganti alat press yang selama ini dilakukan di pohon (sebagai tumpuan pres) dengan alat pres ulir hasil rekayasa tim PKM.

Penggunaan alat pres ulir banyak membantu mitra karena air perasan ditampung dalam ember, tidak lagi menggunakan kayu dan batu karang sebagai beban pengungkit. Selain itu, waktu pengepresan sangat singkat, yang selama ini memerlukan waktu sekitar 6-8 jam, tetapi sekarang hanya sekitar 10-15 menit singkong parut sudah kering. Kondisi ini sangat baik karena banyak mengurangi kandungan asam sianida yang menjadi racun dalam umbi singkong.

\section{- Pembuatan tepung singkong/enbal}

Singkong sebanyak $20 \mathrm{~kg}$ dikupas dan dicuci kemudian direndam selama satu jam dalam air bersih, kemudian diparut menggunaan mesin. Sitepu (2009) menjelaskan bahwa perendaman dapat membantu mengurangi kadar HCN dalam singkong. Selanjutnya hasil parutan diperas menggunakan alat pres ulir. Kemudian digiling menjadi tepung dan diayak sehingga diperoleh tepung singkong yang halus dan putih sebanyak $15 \mathrm{~kg}$. Produksi tepung singkong/enbal terlihat pada Gambar 2.

\section{- Produksi singkong lempeng}

Tepung singkong sebanyak $14 \mathrm{~kg}$ ditata dalam cetakan/porna berbentuk persegi empat dari stainless steel (ukuran panjang $\mathrm{x}$ lebar $\mathrm{x}$ tinggi $=$ $4,5 \times 3 \mathrm{~cm} \times 1,5 \mathrm{~mm}$ ) kemudian dipanggang dalam oven selama kurang lebih 10 menit sehingga terbentuk singkong lempeng yang kaku, kompak, dan sudah matang. Penggunaan api yang tidak terlalu besar membantu pembentukan tekstur singkong lempeng tetapi tidak menjadi hangus. Selanjutnya singkong lempeng dijemur agar teksturnya lebih kompak serta tidak mudah patah saat kering. Produksi enbal lempeng terlihat pada Gambar 3.

\section{- Produksi bubur rumput laut}

Rumput laut kering direndam dalam air beras selama 2 hari, kemudian ditiriskan dan dipotong ukuran 1-2 cm agar mudah diblender. Selanjutnya potongan rumput laut diblender sampai menjadi bubur. Bubur rumput laut di panaskan sampai mendidih kemudian disaring sehingga diperoleh bubur rumput laut yang halus dan bersih siap digunakan sebagai bahan baku singkong krispi. Pembuatan bubur rumput laut terlihat pada Gambar 4.
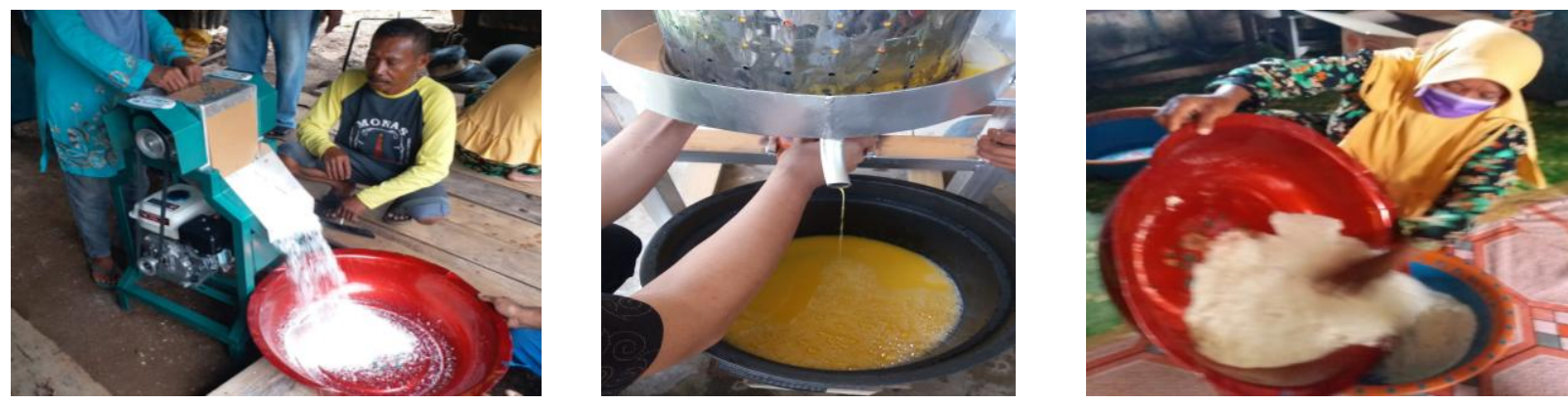

Gambar 2 Produksi tepung singkong/enbal.
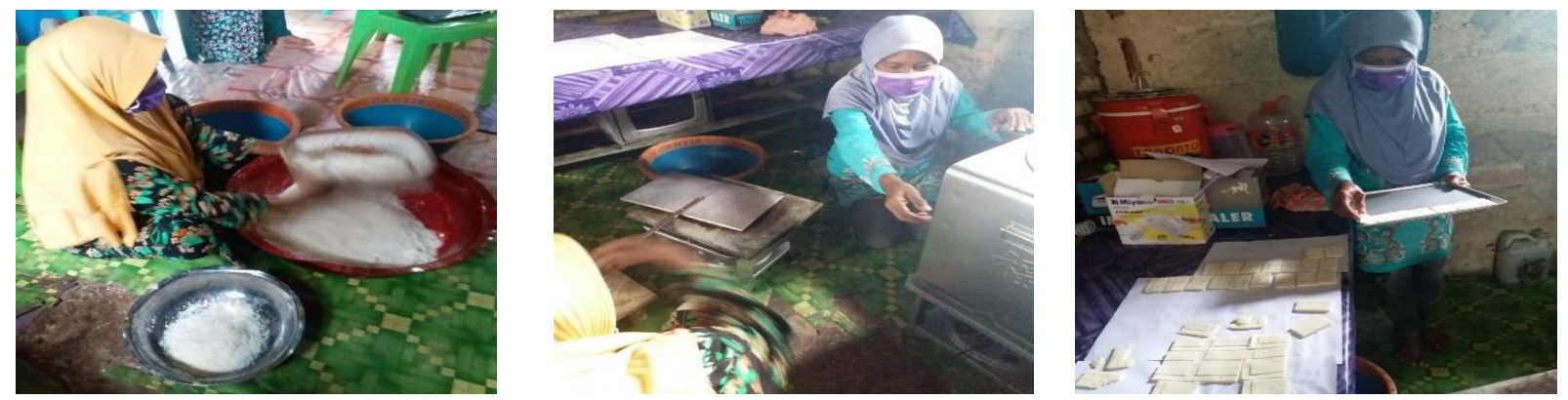

Gambar 3 Produksi enbal lempeng. 


\section{- Produksi singkong krispi rumput laut}

Bahan-bahan adonan (telur, mentega, susu, gula pasir, dan vanili) sesuai takaran dicampurkan dan dimikser sampai halus merata. Bubur rumput laut sebanyak 15\% (dari bobot adonan) ditambahkan ke dalam adonan dan dimikser kembali sampai tercampur merata. Adonan dioleskan secara merata pada permukaan singkong lempeng dengan menggunakan kuas makanan, selanjutnya dipanggang dalam oven sampai matang selama kurang lebih 10 menit. Proses produksi enbal krispi rumput laut terlihat pada Gambar 5.

Selain itu pembuatan SOP produksi sangat membantu mitra dalam menjaga kualitas produk singkong krispi rumput laut. Sebagian besar ilmu yang didapat melalui penyuluhan dan pelatihan produksi SKRL telah diadopsi oleh mitra sehingga perbaikan proses produksi telah membantu perbaikan kualitas produk. Singkong krispi rumput laut yang diproduksi cukup diminati konsumen, baik lokal maupun luar Maluku. Hal ini karena produk singkong krispi memiliki karakteristik rasa enak, gurih, dan krispi. Selain itu tidak digunakannya bahan tambahan pangan (BTP) termasuk pewarna makanan menyebabkan singkong krispi rumput laut menjadi pangan lokal yang sehat. Hasil pengawasan Badan Pengawas Obat dan Makanan (BPOM) pada tahun 2016 yang dikutip Nurcahyo (2018) menunjukkan sekitar $14,9 \%$ dari 26.537 sampel pangan tidak memenuhi syarat karena penyalahgunaan bahan berbahaya, cemaran mikrob atau bahan tambahan pangan (BTP) melebihi batas maksimum yang diizinkan. Selama 6 bulan, singkong krispi rumput laut yang dihasilkan sebanyak 600 dus, dengan berat bersih per kemasan 111 gr. pendapatan mitra selama 6 bulan mencapai Rp 10.000.000.

\section{Strategi Pemasaran dan Manajemen Usaha}

Kualitas produk merupakan salah satu faktor utama dalam meningkatkan daya saing produk singkong kripsi, namun faktor-faktor lain yang tidak kalah penting adalah kemasan yang digunakan. Penggunaan plastik transparan tanpa label yang selama ini digunakan mitra untuk mengemas singkong lempeng telah diganti dengan kemasan dus yang dilengkapi label sesuai Undang-undang pangan pada tahun 2012. Kemasan yang dihasilkan mitra memuat nomor PIRT, isi dalam kemasan, alamat produksi, informasi gizi, serta motto produk yaitu "gerakan cinta produk lokal".

Strategi yang ditampilkan pada kemasan sangat membantu mitra dalam memasarkan produknya (singkong krispi rumput laut) sehingga lebih diminati konsumen. Model kemasan yang agak kecil yang dilengkapi tas, di mana 1 tas berisi 8 dus membuat tampilan produk menjadi lebih berestetik. Menurut Mufreni (2016), desain produk berpengaruh secara signifikan terhadap
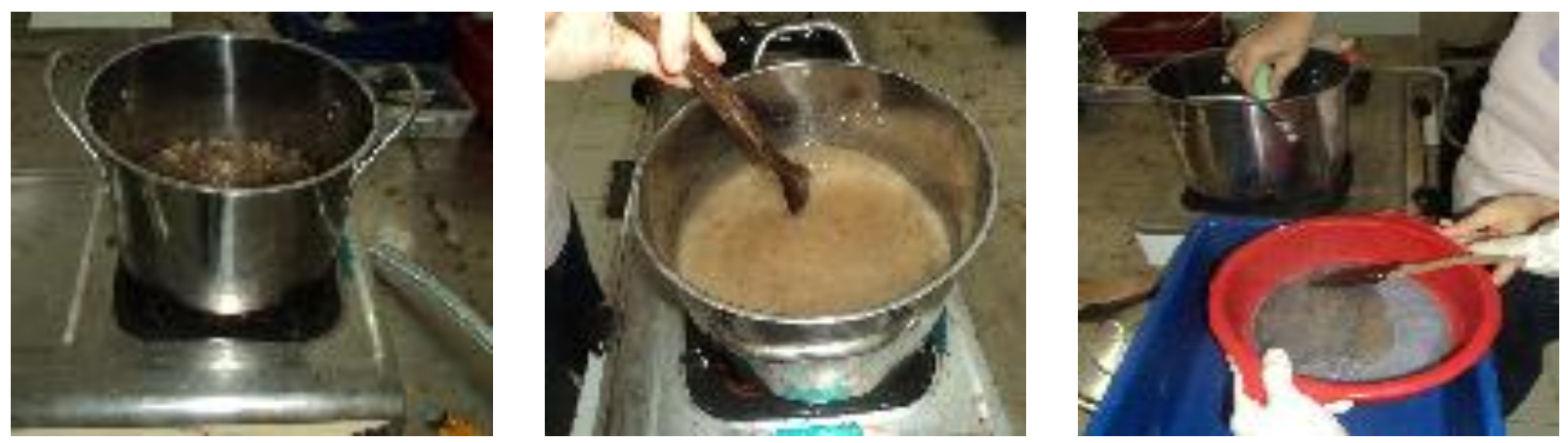

Gambar 4 Pembuatan bubur rumput laut.
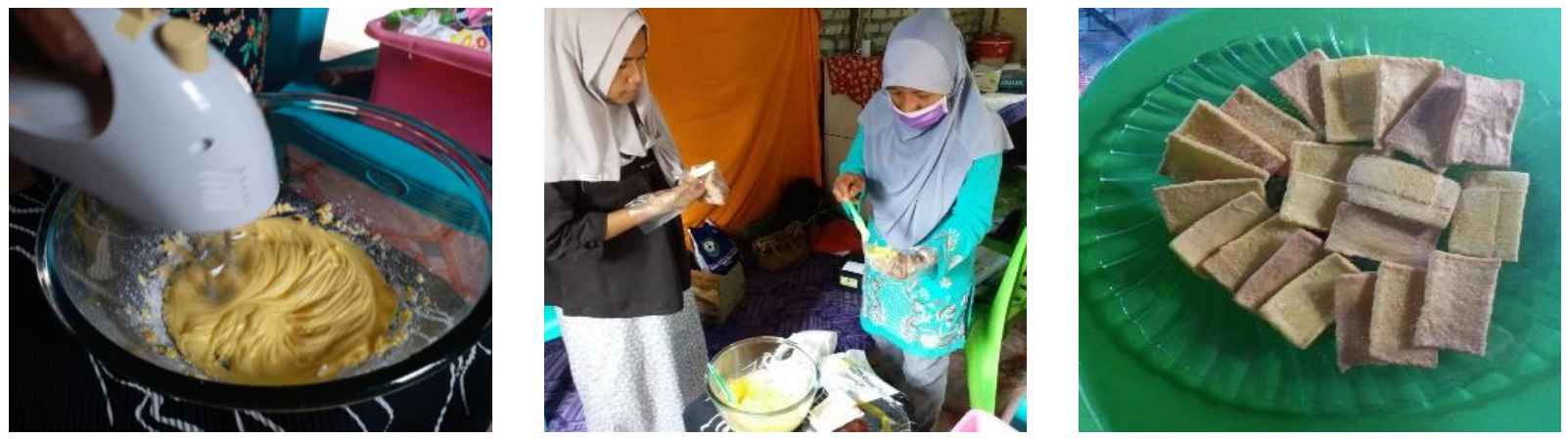

Gambar 5 Proses produksi enbal krispi rumput laut. 
minat beli konsumen. Ditambahkan oleh Mukhtar \& Nurif (2015), bahwa fungsi kemasan yang dulu hanya sebagai wadah atau pelindung, berubah menjadi alat jual yang menciptakan citra kepada produk yang dijual. Strategi pemasaran dengan mendesain kemasan yang lebih marketable membuat produk singkong krispi rumput laut sudah mendapat tempat di hati masyarakat khususnya di Maluku Tenggara.

Pengelolaan usaha melalui penataan manajemen usaha yang dilakukan mitra cukup efektif dalam meningkatkan pemahaman mitra terhadap arus kas keluar masuk. Adanya buku kas sederhana yang memuat pemasukan dan pengeluaran menjadikan mitra bisa mengetahui jumlah pendapatan kotor dan bersih usaha mereka. Dimana sampai dengan 6 bulan kegiatan telah terjual 600 dus dengan penghasilan bersih Rp 10.000.000.

\section{Perubahan pada Mitra}

Tujuan utama dari pelaksanakan kegiatan program kemitraan masyarakat (PKM) adalah membantu hilirisasi hasil riset yang bermanfaat untk pengembangan usaha mitra. Teknologi diversifikasi enbal krispi yang difortifikasi rumput laut telah membuat mitra menjadi bersemangat dalam berproduksi. Pengetahuan mitra menjadi bertambah, hal ini terlihat dengan jawaban yang diberikan saat posttes, di mana sebanyak 95\% mitra mampu menjawab pertanyaan yang diajukan seputar pengetahuan produksi enbal krispi rumput laut. Demikian juga dengan keterampilannya, mitra sudah mampu memproduksi enbal krispi rumput laut dengan sangat baik dan cepat, walaupun masih harus memperbaiki beberapa kekurangan seperti kemulusan olesan adonan dipermukaan enbal serta sanitasi higienis alat yang bersentuhan langsung dengan produk. Hasil kunjungan dinas kesehatan Kabupaten Maluku Tenggara ke lokasi produksi mitra menunjukkan dinas kesehatan mengapresiasi proses kerja produksi enbal krispi yang telah memenuhi standar sanitasi higienis. Hal ini sesuai dengan rekomendasi higiene sanitasi nomor 445/102/2018 yang dikeluarkan dinas kesehatan kabupaten Maluku Tenggara.

\section{SIMPULAN}

Perbaikan proses produksi memberikan dampak terhadap perbaikan kualitas dan tingkat kesukaan konsumen terhadap singkong krispi rumput laut. Perbaikan kemasan menggunakan dua jenis kemasan (primer dan sekunder), mampu menarik minat konsumen terhadap singkong krispi rumput laut. Strategi pemasaran dan perbaikan manajemen usaha mampu memberikan dampak nyata dalam meningkatkan pendapatan usaha mitra, yakni mencapai sepuluh juta rupiah. Produksi singkong krispi rumput laut selama 6 bulan menghasilkan 600 dus dengan pendapatan mencapai Rp 10.000 000. Enbal krispi rumput laut merupakan pangan lokal yang dikembangkan dari usaha masyarakat kecil untuk itu sangat perlu dilanjutkan kegiatan ini dengan intervensi pemerintah daerah setempat terutama dinas atau badan yang berkaitan lansgugn dengan pemberdayaan UKM.

\section{UCAPAN TERIMA KASIH}

Terima kasih disampaikan kepada Direktorat Riset dan Pengabdian kepada Masyarakat, Kemristekdikti RI yang telah membiayai kegiatan PKM pada tahun 2018 ini.

\section{DAFTAR PUSTAKA}

[AOAC] Association of Official Analytical Chemists. 2005. Official Methods of Analysis of AOAC International. Gaithersburg, Maryland (USA): AOAC International.

Almatsier S. 2009. Prinsip Dasar Ilmu Gizi. Jakarta (ID): PT Gramedia Pustaka Utama.

Burtin P. 2003. Nutritional Value of Seaweed. Electronic Journal of Environmental, Agricultural and Food Chemistry. 2(4): 498503.

[DKP] Dinas Kelautan dan Perikanan Malra. 2015. Laporan Tahunan. Dinas Kelautan dan Perikanan Kabupaten Maluku Tenggara. Maluku Tenggara (ID).

Marasabessy I, Sudirjo F. 2017. Seaweed Fortification on Crisyi Enbal as Local Food of Kei Islands. IOP Conference Series: Earth and Environmental Science. Vol 89.

Marasabessy I, Sudirjo F. 2014. Peningkatan Daya Saing Enbal Crispi Sebagai Makanan Khas Daerah Maluku Tenggara Dengan Fortifikasi Serat Pangan Rumput Laut. Laporan 
Penelitian Hibah Bersaing (tahun 2). Tual (ID): Politeknik Perikanan Negeri Tual.

Mufreni ANF. 2016. Pengaruh Desain Produk, Bentuk Kemasan Dan Bahan Kemasan Terhadap Minat Beli Konsumen (Studi Kasus Teh Hijau Serbuk Tocha). Jurnal Ekonomi Manajemen. 2(2): 48-54.

Mukhtar S, Nurif M. 2015. Peranan Packaging Dalam Meningkatkan Hasil Produksi Terhadap Konsumen. Jurnal Sosial Humaniora. 8(2): 181-191.

Nurcahyo E. 2018. Pengaturan dan Pengawasan Produk Pangan Olahan Kemasan. Jurnal Magister Hukum Udayana.7(8): 402-417
Sitepu JM. 2009. Pengaruh Waktu Perendaman Terhadap Penurunan Kadar Asam Sianida (HCN) Pada Ubi Kayu Pahit (Manihot esculenta Grant). Medan (ID): Universitas Sumatera Utara.

SNI [1992]. Syarat Mutu Tepung Ubi Kayu. Standar Nasional Indonesia Nomor 01-29971992. Badan Standarisasi Nasional. Republik Inddonesia.

Tapotubun EJ. 2010. Diversifikasi Produk Enbal Cetak. Laporan Penelitian. Tual (ID): Politeknik Perikanan Negeri Tual. (tidak publikasi). 